\title{
Zbigniew Rykiel
}

Uniwersytet Rzeszowski

\section{Identyfikacja i tożsamość kulturowa w różnych skalach przestrzennych}

STRESZCZENIE W artykule omówiono pojęcia tożsamości społecznej i terytorialnej. Wykazano relacje między etnicznością a terytorialnością. Podkreślono symbolizm terytorialności i jej mitologizację ze szczególnym uwzględnieniem okcydentalizacji i wiktymizacji. Przedyskutowano kwestie wielokulturowości i transkulturowości. Przeanalizowano relacje między nacjonalizmem a tożsamością. Wskazano również neoplemienność w kontekście zderzenia cywilizacji w ramach jednego narodu. Przedstawiono wniosek, że pojęcie tożsamości jest dalekie od jednoznaczności, można je więc łatwo zastąpić pojęciami ideologii, organizacji i solidarności.

\section{Tożsamość społeczna a tożsamość terytorialna}

Tożsamość oznacza utrwaloną, tj. względnie stabilną formę świadomości (Rykiel, 2010). Tożsamość społeczna, jako zwielokrotniona tożsamość indywidualna, nie jest sumą tych tożsamości, lecz systemem ukształtowanym na podstawie wspólnego systemu aksjo-normatywnego (Rykiel, 2016b), obejmuje więc elementy kultury idealnej, w tym zwyczaje, obyczaje, język
SŁOWA KLUCZOWE

TOŻSAMOŚĆ, IDENTYFIKACJA, TERYTORIALNOŚĆ, WIELOKULTUROWOŚĆ, TRANSKULTUROWOŚĆ, NEOPLEMIENNOŚĆ 
i terytorium (Bokszański, 1989). Elementy te mogą być przy tym wartościami lub normami. Tożsamość społeczna jest zatem ponadjednostkowym zbiorem autodefinicji nieredukowalnych do autodefinicji jednostki, tj. do jej identyfikacji; tożsamość społeczna jest więc oparta na przeżywanej i zinternalizowanej tradycji (Banaszczyk, 1989).

Ponieważ tożsamość społeczna obejmuje zespół cech, wynika z tego wielość identyfikacji społecznych jednostki. Wielość ta może być źródłem konfliktu wewnętrznego (Giddens, 2005). Tożsamość społeczna odnosi się raczej do cech przypisywanych jednostce przez innych (Giddens, 2005) niż do obrazu samego siebie, jednostka uświadamia sobie zatem tę tożsamość i odczuwa ją (Rykiel, 2010), co jest źródłem jej autoidentyfikacji. Można zatem stwierdzić, że tożsamość to stabilny, a zwłaszcza potwierdzany przez otoczenie społeczne układ autodefinicji jednostki (Bokszański, 2006).

Tożsamość kulturową definiuje się zazwyczaj jako jedną z form tożsamości społecznej, charakteryzującą się względnie trwałą identyfikacją grupy społecznej i jej członków z danym układem kulturowym, tj. ideami, przekonaniami, poglądami, zwyczajami, obyczajami, wartościami i prawami (Lewandowska, 2003). Ponieważ proces kulturalizacji jest tożsamy z procesem socjalizacji (Sztompka, 2005), gdyż nie może być socjalizacji poza konkretną kulturą ani kulturalizacji poza społeczeństwem, pojęcie tożsamości kulturowej jest tożsame z pojęciem tożsamości społecznej (Rykiel, 2010).

Można przyjąć, że podstawowym elementem tożsamości jest nie tylko identyfikacja jednostki z grupą, ale i z terytorium (Zandecki, 2003), co dotyczy nie tylko społeczności osiadłych, o czym dalej. Tożsamość kulturowa może dotyczyć zbiorowości o różnej skali przestrzennej - od społeczności lokalnej do społeczeństwa globalnego w znaczeniu filologicznym (Rykiel, 2016b). W tym kontekście tożsamość terytorialna byłaby więc częścią tożsamości kulturowej. Chodzi tu bowiem o tożsamość, dla której terytorium jest ważnym elementem odniesienia, przy czym przedmiotem refleksji jest tu terytorium rozumiane relacyjnie, nie zaś substancjalnie, relacyjność ta jest zatem częścią systemu kultury. Wniosek ten opiera się wszakże na założeniu niewielkiej ruchliwości przestrzennej zbiorowości jako całości, co nie wyklucza zresztą znacznej ruchliwości przestrzennej poszczególnych członków tej zbiorowości (Rykiel, 2010). Różne formy i rodzaje przywiązania do własnego terytorium obserwuje się nie tylko we wszystkich kulturach osiadłych (Malmberg, 1980), ale również wśród przednowoczesnych nomadów, którzy wędrują po określonym terytorium (Tuan, 1987), uznawanym za swoje. Prawidłowość ta nie dotyczy natomiast nomadów ponowoczesnych, zwanych turystami (Bauman, 2000) lub supermobilnymi wiecznymi tułaczami (Rykiel, 2006a).

Tożsamość kulturowa jest elementem konstytutywnym wspólnoty terytorialnej (Wieruszewska, 1989). Warunkiem istnienia wspólnoty jest nie tylko uświadomienie sobie przez jednostki wspólnych cech grupy (Lenik, 2002), ale także ich internalizacja i bezrefleksyjna eksternalizacja. Tożsamość społeczna wynika natomiast z podziału innych na swoich i obcych, przy czym podział ten jest częścią procesu socjalizacji-kulturalizacji. W procesie tym terytorium może pełnić dwie funkcje. W ujęciu substancjalnym terytorium jest funkcją areny procesów społecznych, w ujęciu relacyjnym natomiast jest ono korelatem systemu aksjo-normatywnego wspólnoty terytorialnej (Rykiel, 2010). Trwałość wspólnoty terytorialnej wynika zatem z podzielania przez członków tej wspólnoty norm, wartości i sposobów postrzegania przestrzeni społecznej. Częścią tego systemu aksjo-normatywnego jest symbolika terytorialna i mitologia terytorium. Ponieważ zaś system aksjo-normatywny jest częścią kultury, tożsamość terytorialna jest kwestią stopnia uczestnictwa w tej kulturze (Rykiel, 2016b). 


\section{Etniczność a terytorialność}

Tożsamość etniczna nie jest częścią tożsamości terytorialnej, nie jest jej jednak także przeciwstawna (Rykiel, 2010). Terytorium rozumiane substancjalnie - jako część przestrzeni fizycznej - nie musi być bowiem elementem tożsamości etnicznej, ta ostatnia jest bowiem cechą wspólnoty ideologicznej, nie zaś ekologicznej (Kłoskowska, 1996). Terytorium rozumiane relacyjnie natomiast jest częścią przestrzeni społecznej rozumianej raczej jako przestrzeń wartości niż przestrzeń jako wartość, jest więc oczywistym elementem tożsamości etnicznej, gdyż w tym ujęciu terytorium jest korelatem stosunków społecznych (Rykiel, 2016b). Tożsamość etniczna może mieć zatem różną skalę przestrzenną - od lokalnej do globalnej - czego przykładem są wspólnoty diasporowe (Rykiel, 2010).

W tym kontekście wyjaśnienia wymaga kwestia integralności tożsamości. Na danym szczeblu organizacji terytorialnej tożsamości integralne, rozumiane jako poczucie więzi jednostki z tylko jedną grupą społeczną, są bardzo rzadkie, są one bowiem częścią spektrum od uniwalencji, przez biwalencję i poliwalencję, do ambiwalencji (Kłoskowska, 1996). W kontekście nieterytorialnym uniwalencja ani nawet biwalencja nie występuje w złożonym świecie społecznym nowoczesności, a zwłaszcza ponowoczesności. W kontekście różnych szczebli organizacji terytorialnej uniwalencja dotyczy natomiast zasadniczo społeczeństw przednowoczesnych. Dla współczesności jest natomiast typowa tożsamość terytorialna odnosząca się do różnych szczebli organizacji przestrzennej jednocześnie (Smolicz, 1990), przy czym siła więzi na poszczególnych szczeblach hierarchicznych jest kwestią empiryczną (Rykiel, 2016b). Empirycznie stwierdza się więc istnienie tożsamości hybrydowych (Bagnoli, 2007), rozumianych w kategoriach asymilacji jedynie do kultury wybranych elementów wspólnych (Wnuk-Lipiński, 2004).

\section{Symbolika terytorialności i jej mitologizacja}

Symbol jako wytwór kultury jest wzorem zachowań: identyfikacji jako swojego albo odrzucenia jako nie swojego, a więc obcego (Damrosz, 1988). Wspólna konwencja kulturowa umożliwia nadawanie symbolom wspólnych znaczeń, a więc kojarzenie poszczególnych symboli z poszczególnymi obiektami, co umożliwia komunikację społeczną (Rykiel, 2010), istotną w procesie kształtowania się identyfikacji jednostki (Lenik, 2002) i tożsamości wspólnoty (Rykiel, 2010). Dla wspólnot terytorialnych do podstawowych symboli zalicza się przestrzeń (Jałowiecki, 1988), zwłaszcza zaś terytorium, któremu nadaje się znaczenia symboliczne dla danej kultury, a nawet mityczne (Rykiel, 2010).

Mitologia jest istotną częścią tożsamości społecznej, w tym terytorialnej (Gellner, 1991), ponieważ wspólnota terytorialna jest zbiorowością wyobrażoną (Anderson, 1997; Rykiel, 2006b). W kulturze znacznej części Europy - na wschód od osi Renu - dominuje okcydentalizacja tożsamości europejskich budowanych na wizji obrony kultury zachodniej, osaczonej przez barbarzyńców ze Wschodu. Wynika z tego orientalizacja kresów w znacznej części Europy (Rykiel, 2006b) oraz mitotwórczość okcydentalnych cech kultury jako źródła własnej wyższości kulturowej, przeciwstawianych stygmatyzującym orientalnym cechom tej kultury (Zarycki, 2005), postrzeganych jako barbarzyńskie. W tym kontekście pojawia się tendencja nie tylko manifestowania swojej przynależności do Zachodu, ale też przemilczania albo bagatelizowania swych związków z kulturą Wschodu (Zarycki, 2005).

Elementem każdej tożsamości narodowej i regionalnej (Zarycki, 2005), a nawet każdej tożsamości terytorialnej (Rykiel, 2010), jest wiktymizacja, co dotyczy zwłaszcza zbiorowości 
peryferyjnych. W takich wspólnotach dominuje eksponowanie własnego cierpienia oraz masochistycznego użalania się nad sobą (Kwaśniewski, 1997). Zjawisko to można rozpatrywać w kategoriach substytucji nikłego kapitału ekonomicznego kapitałem społecznym, a zwłaszcza kulturowym (Zarycki, 2005). Cierpienia historyczne rozpatruje się wówczas w kategoriach kapitału symbolicznego, niezbędnego do obrony własnych norm i wartości, tworzącego poczucie własnej wyższości moralnej wobec otoczenia. Zagrożenie zewnętrzne - faktyczne lub wyimaginowane - jest wówczas źródłem zaufania, solidarności wewnątrzgrupowej i integracji. Ostentacyjne ofiary są dowodem istnienia tradycyjnej wspólnoty (Gemeinschaft), w której dominuje ta forma kapitału (Zarycki, 2005), oparta na etosie cierpienia, postrzeganego jako inwestycje symboliczne w kapitał społeczny (Rykiel, 2016b).

W przypadku Polski wątek wiktymizacyjny jest widoczny w odniesieniu do wspólnoty narodowej oraz wspólnot regionalnych i lokalnych. Na szczeblu narodowym oczywistym tego przykładem była koncepcja mesjanizmu, na szczeblu regionalnym - znany mit „śląskiej krzywdy" na Górnym Śląsku, na szczeblu lokalnym zaś m.in. koncepcja zielonogórskiego postkolonializmu (Maksymczak, 2007; Rykiel, 2015). We wszystkich tych przypadkach sprawcami wszelkich cierpień - bardziej nawet symbolicznych niż fizycznych - są obcy, koniecznie jednak ze Wschodu (Rykiel, 2016b).

W tym kontekście społecznym rozwijają się okcydentalistyczne mitologie wspólnot terytorialnych, gdzie przedmiotem mitotwórstwa są „stare dobre czasy”. Są one „dobre”, gdyż znane, oswojone i zinternalizowane, przede wszystkim zaś pamiętane wybiórczo. W przypadku Polski był to mit powrotu do Europy, w przypadku Górnego Śląska - mit etosu pracy fizycznej w epoce drugiej fali Tofflera, z dominującym w niej kapitałem ekonomicznym, w przypadku zaś Zielonej Góry - ucieczka w mit pruskiego porządku i pruskich tradycji (Rykiel, 2016b).

\section{Wielokulturowość a transkulturowość}

Kwestię relacji między wielokulturowością a transkulturowością można rozpatrywać na tle kreacji tożsamości lokalnych, zwłaszcza w kontekście tworzenia marki miejsca, w tym zwłaszcza miasta (Rykiel, 2016b). Działanie to polega na kreowaniu wyobrażeń, na celowym albo podświadomym wyolbrzymianiu jednych cech miasta, bagatelizowaniu zaś albo pomijaniu innych. Kreuje się z reguły wyobrażenia skrajne, odwołujące się albo do uniwalencji miasta, albo do jego poliwalencji, pomijając natomiast biwalencję i deprecjonując ambiwalencję.

Przypadek poliwalencji polega na kreowaniu wyobrażeń o wielokulturowości miasta, która faktycznie w ciągu dziejów była jedynie transkulturowością. Przypadek ten odnosi się do narracji dziejów miast na polskich ziemiach zachodnich, przede wszystkim Wrocławia i Gdańska. Przez ponad trzy powojenne dekady XX wieku narracja ta odwoływała się do czasów przedniemieckich i poniemieckich, podczas gdy historia czasów niemieckich była ignorowaną luką w tej narracji (Rykiel, 2013). Wynikało to z przyjętej po wojnie przez władze państwowe - i zaakceptowanej społecznie w kontekście traumy wojennej - ideologii „ziem odzyskanych” lub nawet „ziem piastowskich”, która miała podstawy w odniesieniu tylko do niektórych z tych ziem i to w zróżnicowanym stopniu. Narracja ta zaczęła się zmieniać w latach 70. XX wieku w związku z wygasaniem powojennej traumy oraz jej podstaw politycznych, społecznych i psychologicznych. Do narracji o dziejach tych miast zaczęto więc wówczas wplatać coraz liczniejsze wątki z niemieckiego okresu historii. Od lat 90. XX wieku można zauważyć wyraźny przełom w tej dziedzinie. Przełom ten polegał, po pierwsze, 
na rozpowszechnianiu się narracji o dziejach lokalnych poszczególnych miast, co traktowano jako kontrapunkt dla historii narodowej, po drugie na snuciu narracji o całości dziejów lokalnych - bez „niepoprawnych politycznie” luk (Rykiel, 2013). Te nowe, pełniejsze narracje pokazały analogie losów obu rywalizujących o dane miejsce wspólnot narodowych, tj. zarówno niemieckich „wypędzonych”, jak i polskich „repatriantów” (Davies, Moorhouse, 2011), ukazując ideologizację tych kategorii pojęciowych.

Współczesny Wrocław uchodzi za to miasto polskie, które najlepiej wykorzystało wizerunkowo przełom ustrojowy 1989 roku, budując swą markę miasta wielokulturowego (Rykiel, 2013). Norman Davies i Roger Moorhouse (2011) wskazali, że tę wielokulturowość Wrocławia można interpretować albo jako kosmopolityzm, albo jako transkulturowość, przy czym ta ostatnia może być bardziej dopełnieniem niż przeciwstawieniem wielokulturowości.

Przypadek uniwalencji odnosi się natomiast do kreowania odmiennych pamięci zbiorowych tego samego miejsca przez rywalizujące o to miejsce wspólnoty narodowe lub etniczne. Dobrym tego przykładem jest polsko-litewska rywalizacja pamięci o Wilnie jako mieście odwiecznie polskim albo odwiecznie litewskim (Rykiel, 2016b), przy czym każda z rywalizujących stron wskazuje na inne aspekty aspektów tożsamości. Strona polska odwołuje się więc do dziejów Pierwszej Rzeczypospolitej, utożsamianej bezzasadnie z Rzecząpospolitą Polską, oraz do liczebnej przewagi mieszkańców polskojęzycznych przynajmniej od początku XX wieku, pomija natomiast fakt, że Wilno nigdy nie należało do Polski przed 1922 rokiem, a polskojęzyczni mieszkańcy Wileńszczyzny uważali się za Litwinów, chociaż z biegiem wieków i dziesięcioleci swą litewskość rozumieli w coraz większym stopniu jako regionalną odmianę polskości. Strona litewska odwołuje się natomiast do odrębności Wielkiego Księstwa Litewskiego od Korony w ramach Rzeczypospolitej Obojga Narodów, odrębność tę nadmiernie eksponując oraz ignorując powszechną biwalencję polsko-litewską, bynajmniej nie tylko na Wileńszczyźnie, co najmniej od połowy XIX wieku.

\section{Nacjonalizm a tożsamość}

Termin nacjonalizm jest używany w literaturze w dwóch zasadniczych znaczeniach. W Europie Zachodniej i świecie anglosaskim jest to termin opisowy, w Europie Środkowo-Wschodniej i Wschodniej natomiast - normatywny, z konotacjami pejoratywnymi, wskutek czego jego znaczenie jest bliskie egoizmu narodowego, a może nawet szowinizmu (Rykiel, 2016a).

W przypadku terminu naród sytuacja jest podobna. W Europie Środkowo-Wschodniej i Wschodniej naród jest rozumiany etnicznie, w Europie Zachodniej natomiast i w obu Amerykach - politycznie. W tym kontekście państwo narodowe jest w Europie Środkowo-Wschodniej i Wschodniej organizacją polityczną narodu etnicznego, podczas gdy w Europie Zachodniej jest ono desygnatem narodu budowanego w ramach danego państwa, a w krajach anglosaskich - nawet z nim utożsamianego (Rykiel, 2006b). Za przejawy nacjonalizmu uznaje się wówczas biurokratyzację, ideologizację i solidarność (Malešević, 2013). Nacjonalizm można zatem rozpatrywać na tle innych - przednarodowych - form solidarności grupowej. Takie rozumowanie prowadzi do wniosku, że solidarność ludów wędrownych przekształcała się historycznie w solidarność ludów osiadłych, a przykłady pozanarodowych lojalności terytorialnych dostarczają, z jednej strony, miasta-państwa, z drugiej zaś - imperia światowe.

Pojawienie się i ekspansję nacjonalizmu można zatem rozpatrywać, analizując pojawienie się państwa narodowego jako organizacji społecznej (Malešević, 2013). Warto tu jednak zauważyć złożone relacje między ideologiami narodowymi a przemocą. Punktem wyjścia do 
analizy tych mechanizmów może być spostrzeżenie, że obce kultury we własnym państwie narodowym są skandalem (Langewiesche, 2002). W tym kontekście pojawia się kwestia omnipotencji i trywialności nacjonalizmu, co można sprowadzić do dualizmu nacjonalizmu gorącego i banalnego (Malešević, 2013). Kwestia tożsamości narodowej okazuje się wówczas procesem przekształcania się organizacji społecznej i ideologii w solidarność.

Podstawą solidarności grupowej, ale i suwerenności ludu, były hasła rewolucji francuskiej, ucieleśnione także w rewolucji amerykańskiej, o wolności, równości i braterstwie, z czego wyrosła idea państwa narodowego. Podstawowe znaczenie miała jednak ideologia i organizacja biurokratyczna. Państwo jest bowiem organizacją socjalizującą jednostki do ideologii narodowej przez efektywny aparat biurokratyczny, naród jest zatem rezultatem działania państwa narodowego (Malešević, 2013). Narody konstytuowały się jednak nie tylko w ramach państw narodowych, lecz także w opozycji do nich, czego liczne przykłady można znaleźć zwłaszcza w Europie Środkowo-Wschodniej (Rykiel, 2014).

Wbrew zatem ideologiom narodowym, państwo nie jest wspólnotą (Gemeinschaft), lecz zrzeszeniem (Gesellschaft), ponieważ członków narodu nie łączą więzi pokrewieństwa ani nawet wspólnej kultury, lecz wyłącznie wspólnej ideologii i efektywnej biurokracji. To za ich bowiem pomocą państwo narzuciło ludom na swym terytorium przekonanie, że są one jednym i wspólnym narodem (Malešević, 2013). W XIX wieku dokonało się to w Europie, w XX wieku natomiast - ku zaskoczeniu Europejczyków - w Afryce. Do zrozumienia tego fenomenu przydatna jest koncepcja wchodzenia do narodu kolejnych klas społecznych (Chałasiński, 1968), ale także zbiorowości regionalnych (Rykiel, 2006b).

Narodowa solidarność grupowa realizuje się zasadniczo przez więzi mikrostrukturalne (Malešević, 2013). Jednostki rzadko więc były skłonne umierać za ojczyznę, znacznie natomiast częściej za swych bliskich. Internalizacja, a następnie eksternalizacja więzi narodowych wiąże się z ich - wspomnianą już - mitologizacją. Głęboka wiara w wartość poświęcenia się dla abstrakcyjnej zbiorowości, w tym dla ojczyzny, nie jest więc wcale oczywista (Rykiel, 2014), internalizacja ta bowiem i eksternalizacja są procesami, nie zaś jednorazowymi aktami.

Istotne jest odróżnianie nacjonalizmu ideologicznego i codziennego, tj. banalnego w znaczeniu nadanym przez Hannę Arendt (1998). Co ciekawe, ten drugi rodzaj nacjonalizmu jest silniejszy i efektywniejszy, gdyż zinternalizowany (Malešević, 2013). Porównanie nacjonalizmu północnokoreańskiego z duńskim potwierdza to spostrzeżenie, ten pierwszy jest bowiem jedynie bardziej hałaśliwy, a może i spektakularny (Malešević, 2013), mniej zaś efektywny w kategoriach socjologii codzienności (Rykiel, 2014).

W świetle powyższych argumentów koncepcja tożsamości narodowej okazuje się mglista, a tożsamość - głównie metaforyczna, ideologię tożsamości można zatem zastąpić pojęciami ideologii, solidarności i organizacji społecznej (Malešević, 2013). Tożsamość narodowa nie jest bowiem kwestią przynależności do grupy, lecz kwestią stopnia uczestnictwa w kulturze narodowej (Kłoskowska, 1996).

W ujęciu opisowym nacjonalizm nie ma, jak się zdaje, alternatywy, gdyż państwo narodowe jest obecnie dominującą formą organizacji społecznej, a sam nacjonalizm - głównym źródłem legitymizacji państwa (Malešević, 2013). Państwo narodowe jako organizacja społeczna jest więc powszechnie uznawana za najbardziej naturalną formę solidarności grupowej (Malešević, 2013).

Wynika to z faktu, że państwo narodowe jest wprawdzie przymusową organizacją biurokratyczną, nie jest ono jednak zwykłym narzędziem prania mózgów, nacjonalizm nie jest 
zaś wyrafinowanym kłamstwem. Wprost przeciwnie, państwo narodowe jest obecnie uznawane przez przeważającą większość swych obywateli za najsilniej legitymizowaną formę panowania (Malešević, 2013), ponieważ opiera swą legitymizację na ideach suwerenności ludu, autonomii terytorialnej i znacznej homogeniczności kulturowej.

\section{Neoplemienność a zderzenie cywilizacji}

Zjawisko zderzenia cywilizacji (Huntington, 2007) opisywano klasycznie w skali globalnej. Jak jednak wskazano gdzie indziej (Rykiel, 2016a), można je powiązać z koncepcją neoplemion (Maffesoli, 2008) jako wspólnot pasji i przenieść na grunt zderzenia cywilizacji w ramach jednego narodu. W tym kontekście Zbigniew Mikołejko odwołuje się do feudalnego podziału na Polskę szlachecką i chłopską (Kowalska, 2015). Kulturę szlachecką przejęła na przełomie XIX i XX wieku inteligencja, chłopską zaś - głównie za sprawą industrializacji socjalistycznej - robotnicy.

Marek J. Minakowski (2014) wskazuje, że może to być część większej całości, jaką była rewolucja społeczna, która - po raz pierwszy od połowy XIX wieku - dokonała się w Polsce dopiero w 1990 roku. Była to rewolucja - dopuszczonej w tym czasie na masową skalę do szkolnictwa wyższego - klasy chłopskiej, a co najmniej warstw plebejskich, przeciwko etosowi inteligenckiemu, którego nosicielami byli potomkowie drobnej szlachty i słabego mieszczaństwa. Przez cały XX wiek inteligencja reprodukowała się zgodnie ze schematem Pierre'a Bourdieu przez swój habitus, do którego adaptowały się także elity komunistyczne. Tę adaptację należy jednak rozpatrywać w kontekście historycznym. W czasie okupacji hitlerowskiej i stalinowskiej tradycyjna inteligencja została bowiem zdziesiątkowana, a system komunistyczny zakończył ten proces (Jałowiecki, 2016).

Na miejsce inteligencji weszła na scenę dziejową „inteligencja pracująca”, tj. ludzie bez tradycji, etosu, manier i kompetencji językowych. Społeczeństwo stało się więc w znacznej mierze chłopskie (Jałowiecki, 2016). Obrady okrągłego stołu i wybory kontraktowe z 1989 roku były „łabędzim śpiewem polskiej inteligencji” (Minakowski, 2014), symbolem polskiej rewolucji proletariackiej natomiast - zwycięstwo Lecha Wałęsy w wyborach prezydenckich z 1990 roku nad Tadeuszem Mazowieckim (Jałowiecki, 2016; Minakowski, 2014). Co ważniejsze strukturalnie, w tymże roku wiek emerytalny osiągnęli profesorowie, którzy zdawali maturę w roku szkolnym 1938/1939, tj. pokolenie, do którego należeli rektorzy i ministrowie szkolnictwa wyższego. Stracili oni wtedy bezpośredni wpływ na wychowanie kolejnych pokoleń studentów, a opuszczone w ten sposób miejsce zajęli „marcowi docenci” (Minakowski, 2014), tj. osoby awansowane z powodów politycznych po 1968 roku.

Zbiegło się to w czasie z umasowieniem studiów. Dopuszczone masowo do szkół wyższych warstwy plebejskie nie przejęły etosu inteligenckiego, przedkładającego kapitał kulturowy nad ekonomiczny, lecz skupiły się na osiąganiu tego ostatniego, poświęcając wolność na rzecz zewnętrznych atrybutów sukcesu w społeczeństwie konsumpcyjnym (Rykiel, 2016a). Brak aspiracji inteligenckich wśród młodzieży studiującej po 1990 roku (Minakowski, 2014) jest skutkiem i symptomem schyłku inteligencji jako siły elitotwórczej (Jałowiecki, 2016).

Miejsce to zajęło neoplemię schodzących obecnie ze sceny dziejowej zaściankowych tradycjonalistów, którzy lęk przed swym schyłkiem manifestują łabędzim śpiewem, a raczej rykiem rannego zwierza przed agonią (Rykiel, 2016a). Spektakularnym wyrazem konfliktu neoplemion było w 2015 roku zdjęcie zegara w kancelarii premiera i zastąpienie go przez krzyż (Kowalska, 2015). 
Ta symboliczna zmiana jest odzwierciedleniem zderzenia cywilizacji, gdyż zegar symbolizuje czas liniowy (chronos - xpóvos), chronologiczny, mechaniczny, mierzalny, określony przez cywilizację oświeceniową i nowoczesną, podczas gdy krzyż reprezentuje czas archaicznej cywilizacji symboli, obrzędów i rytuałów (kairós - kaıpóc). Zwolennicy cywilizacji symboli wywodzą się „z zastygłych rzeczywistości kulturowych i społecznych” (Kowalska, 2015), godząc się na techniki i technologie nowoczesności, nie akceptując natomiast nowoczesnej mentalności, związanej z otwartością, ruchliwością, różnorodnością i odmiennością oraz z akceptacją innego, a nawet z jego zrozumieniem (Kowalska, 2015). Nie chcą więc i, co gorsza, nie potrafią porzucić zastygłych struktur społecznych, w których zostali zsocjalizowani, które oswoili i zinternalizowali.

Symptomy zmian kulturowych i mentalnych, wyzwania postępu i otwarcia się na zróżnicowany świat, pluralizm stylów życia, norm i wartości neoplemię zaściankowych tradycjonalistów traktuje jako zagrożenie dla swej swojskości w archaicznym świecie tradycyjnych gestów, zachowań, symboli, obrzędów, zewnętrznej religijności, a także mitów (Kowalska, 2015; Rykiel, 2016a). Zmiany, jakie niesie ponowoczesność, są bolesne, gdyż stanowią wyzwanie zarówno dla tradycji feudalnego i ludowego katolicyzmu, jak i komunizmu (Kowalska, 2015). Paradoksalnie bowiem realny komunizm był przez całe dekady tradycjonalistyczny, a więc - paradoksalnie - swojski dla neoplemienia zaściankowych tradycjonalistów. Stąd tylko pozornie paradoksalny powrót politycznej reprezentacji tego neoplemienia do kultury politycznej i rozwiązań organizacyjnych PRL-u. Neoplemię lewicowo-liberalne, wymagające racjonalności myślenia i zachowań oraz otwarcia się na pluralizm, tę zaściankową swojskość burzy, podważając sensowność świata społecznego neoplemienia zaściankowych tradycjonalistów. Temu ostatniemu wali się więc świat społeczny, którego nie jest gotowe porzucić, sami zaś jego członkowie - bez sprzeciwu wymrzeć (Rykiel, 2016a). Uruchamia to „ogromne pokłady lęku” (Kowalska, 2015) i agresji, skierowanej także na media, które ukazują, a nawet obnażają nieoczywistość, a może nawet absurd, egzystencji tradycjonalistycznej, z jej tanią emocjonalnością (Kowalska, 2015) konstruowaną za pomocą ubogich komunikacyjnie symboli, mitów i sloganów, powtarzanych raczej nabożnie niż rozumnie (Kowalska, 2015; Rykiel, 2016a). Rezultatem jest uczulenie na ironię i krytykę, odbierane jako atak osobisty, co jest niewątpliwym przejawem głębokich kompleksów zbiorowości zaściankowych.

\section{Zakończenie}

Ugruntowane w naukach społecznych pojęcie tożsamości kulturowej, jeśli w ogóle ma odpowiednik w świecie realiów (Jullien, 2016), jest dalekie nie tylko od jednoznaczności, ale i od jasności, można je bowiem zastąpić pojęciami ideologii, organizacji społecznej i solidarności. Jako ideologia tożsamość przejawia się w postaci normatywnej oraz w postaci banalnej codzienności, przy czym ta druga jest efektywniejsza, gdyż głęboko zinternalizowana i automatycznie eksternalizowana. Jako ideologia i organizacja tożsamość podlega kreowaniu, jako taka jest więc elementem nie tylko socjalizacji i kulturalizacji, lecz także indoktrynacji (Rykiel, 2016b). Częścią tego zjawiska jest utożsamianie tożsamości z identyfikacją. 


\section{LITERATURA}

Anderson, B. (1997). Wspólnoty wyobrażone. Rozważania o źródłach i rozprzestrzenianiu się nacjonalizmu. Warszawa: Znak.

Arendt, H. (1998). Eichmann w Jerozolimie. Rzecz o banalności zła. Kraków: Znak.

Bagnoli, A. (2007). Between Outcast and Outsider: Constructing the Identity of the Foreigner. European Studies, 9 (1), 23-44.

Banaszczyk, T. (1989). Studia o przedstawieniach zbiorowych czasu i przestrzeni w durkheimowskiej szkole socjologicznej. Wrocław: Ossolineum.

Bauman, Z. (2000). Globalizacja i co z tego dla ludzi wynika. Warszawa: PIW.

Bokszański, Z. (1989). Tożsamość - interakcja - grupa. Tożsamość jednostki w perspektywie teorii socjologicznej. Łódź: Wydawnictwo UŁ.

Bokszański, Z. (2006). Tożsamości zbiorowe. Warszawa: PWN.

Chałasiński, J. (1968). Kultura i naród. Warszawa: PWN.

Damrosz, J. (1988). Symbolika regionu wyznacznikiem odrębności. W: D. Simonides (red.), Symbolika regionów. Studia etnograficzno-folklorystyczne (9-28). Opole: Wydawnictwo Instytutu Śląskiego.

Davies, N., Moorhouse, R. (2011). Mikrokosmos. Portret miasta środkowoeuropejskiego. Vratislavia - Breslau - Wrocław. Kraków: Znak.

Gellner, E. (1991). Narody i nacjonalizm. Warszawa: PIW.

Giddens, A. (2005). Socjologia. Warszawa: PWN.

Huntington, S. (2007). Zderzenie cywilizacji i nowy kształt ładu światowego. Warszawa: WWL Muza.

Jałowiecki, B. (1988). Społeczne wytwarzanie przestrzeni. Warszawa: KiW.

Jałowiecki, B. (2016). Śmierć inteligencji. Polityka, 18 (3057), 79.

Jullien, F. (2016). I/ n'y a pas d'identité culturelle. Paris: Édition de l'Herne.

Kłoskowska, A. (1996). Kultury narodowe u korzeni. Warszawa: PWN.

Kowalska, D. (2015). Prof. Mikołejko: W Polsce walczą ze sobą dwie cywilizacje. Słychać łabędzi śpiew tradycjonalistów. Polska. Pobrane z: http://www.polskatimes.pl/ artykul/9219405,prof-mikolejko-w-polsce-walcza-ze-soba-dwie-cywilizacje-slychac-labedzi-spiew-tradycjonalistow, 1 ,id,t,sa.html.

Kwaśniewski, K. (1997). Społeczne rozumienie relacji kresów i terytorium narodowego. W: K. Handtke (red.), Kresy - pojęcie i rzeczywistość (63-84). Warszawa: Slawistyczny Ośrodek Wydawniczy.

Langewiesche, D. (2002). Naród, regionalizm, państwo narodowe: stan i perspektywy badań. Sprawy Narodowościowe. Seria Nowa, 20, 11-55.

Lenik, S. (2002). Tożsamość narodowa młodych Polaków. Częstochowa: WSP.

Lewandowska, I. (2003). Historyczna świadomość regionalna. Z badań nad młodzieżą licealną Warmii i Mazur. Olsztyn: Rozprawy i Materiały Ośrodka Badań Naukowych im. Wojciecha Kętrzyńskiego w Olsztynie, 214.

Maffesoli, M. (2008). Czas plemion. Schyłek indywidualizmu w społeczeństwach ponowoczesnych. Warszawa: PWN. 
Maksymczak, P. (2007). Lubuski postkolonializm. Puls, 5 (105), 26.

Malešević, S. (2013). Nation-states and Nationalisms: Organization, Ideology and Solidarity. Cambridge: Polity Press.

Malmberg, T. (1980). Human Territoriality. The Hague: Mouton Publishers.

Minakowski, M.J. (2014). Leder się myli - rewolucja w Polsce była w 1990, nie 1946 r. Pobrano z: http://minakowski.pl/leder-sie-myli-rewolucja-w-polsce-byla-w-1990-nie-1946-r/.

Rykiel, Z. (2006a). Globalność a lokalność. W: B. Jałowiecki, W. Łukowski (red.), Społeczności lokalne - teraźniejszość i przyszłość (57-66). Warszawa: Scholar, Academica.

Rykiel, Z. (2006b). Podstawy geografii politycznej. Warszawa: PWE.

Rykiel, Z. (2010). Tożsamość terytorialna jako uczestnictwo w kulturze. W: Z. Rykiel (red.), Tożsamość terytorialna w różnych skalach przestrzennych (17-31). Rzeszów: Wydawnictwo Uniwersytetu Rzeszowskiego.

Rykiel, Z. 2013. Vratislavia interculturalis. Przestrzeń Społeczna (Social Space), 6, 133-141.

Rykiel, Z. (2014). Ideological and banal rather than normative nationalism. Przestrzeń Społeczna (Social Space), 7, 173-177.

Rykiel, Z. (2015). Tożsamość, organizacja i eschatologia w perspektywie humanistycznej. Rzeszów: Wydawnictwo Uniwersytetu Rzeszowskiego.

Rykiel, Z. (2016a). Śmieszność semiperyferii. Przestrzeń Społeczna (Social Space), 11, 7-17.

Rykiel, Z. (2016b). Tożsamość terytorialna, nacjonalizm i kreacja tożsamości lokalnej. W: M. Wójcicka, M. Dziekanowska (red.), Współczesne kreacje tożsamości społeczno-kulturowych (9-20). Lublin: UMCS.

Smolicz, J.J. (1990). Kultura i nauczanie w społeczeństwie wieloetnicznym. Warszawa: PWN.

Sztompka, P. (2005). Socjologia: analiza społeczeństwa. Kraków: Znak.

Tuan, Y.F. (1987). Przestrzeń i miejsce. Warszawa: PIW.

Wieruszewska, M. (1989). Tożsamość kulturowa jako wartość i czynnik konstytutywny społeczności lokalnej. W: B. Jałowiecki, K. Sowa, P. Dutkiewicz (red.), Społeczności lokalne. Teraźniejszość i przyszłość (302-324). Warszawa: Uniwersytet Warszawski: Universitas; seria Rozwój Regionalny, Rozwój Lokalny, Samorząd Terytorialny, t. 20.

Wnuk-Lipiński, E. (2004). Świat międzyepoki: globalizacja, demokracja, państwo narodowe. Kraków: Znak.

Zandecki, J. (2003). Modele integracji europejskiej: nawigacja między Europą państw a Europą regionów. W: P. Buczkowski, K. Bondyra, P. Śliwa (red.), Jaka Europa? Regionalizacja a integracja. Poznań: Wydawnictwo Wyższej Szkoły Bankowej.

Zarycki, T. (2005). Uciemiężona forpoczta Zachodu. Wiktymizacja i okcydentalizacja we współczesnym polskim dyskursie regionalnym. Kultura i Społeczeństwo, 49 (2), 115-133. 
SUMMARY The notions of social and territorial identities are discussed in the paper. Relations between ethnicity and territoriality are indicated. The symbolism of territoriality and its mythologisation is pointed to, in which strategies of occidentalisation and victimisation play their parts. The questions of multiculturalism and transculturalism are discussed. The relations between nationalism and identity are analysed. Neo-tribes are considered in the context of the clash of civilisations within one nation. It is concluded that the notion of identity is far from being unequivocal and can be easily substituted by those of ideology, social organisation and solidarity.

\section{KEYWORDS}

IDENTITY, IDENTIFICATION, TERRITORIALITY, MULTICULTURALISM, TRANS-CULTURALISM, NEO-TRIBALISM 